\title{
"Prevalence, Predictors and Outcomes of Surgical and Gastrointestinal Bleeding Events in Patients with COVID-19 Infection on Anticoagulation"
}

Ahmed Alkhamis ( $\square$ ahmed.alkhamis@ku.edu.kw)

Kuwait University https://orcid.org/0000-0002-4732-8471

Yousef Alshamali

Ministry of Health

Khaled Alyaqout

Ministry of Health: Gobierno de Chile Ministerio de Salud

Eisa Lari

Ministry of Health

Moh A. Alkhamis

Kuwait University

Saad Althuwaini

Ministry of Health

Ali Lari

Ministry of Health

Maryam Alfili

Ministry of Health

Ali Alkhayat

Ministry of Health

Mohammad H Jamal

Kuwait University

Salman Alsabah

Kuwait University

Research article

Keywords: COVID-19 Infection, Anticoagulation, Gastrointestinal Bleeding Events, Patients, Infectious Diseases

Posted Date: March 31st, 2021

DOI: https://doi.org/10.21203/rs.3.rs-366340/v1 
License: (c) (i) This work is licensed under a Creative Commons Attribution 4.0 International License. Read Full License 


\section{Abstract}

\section{Background}

This study aims to examine risk factors and complications associated with bleeding events in patients with coronavirus 19 (COVID-19) who are on anticoagulation.

\section{Method}

We conducted retrospective review of a prospectively maintained database of all patients who were admitted with COVID-19 and developed bleeding events.

\section{Results}

Of 122 bleeds, there were 67 (28\%) non-gastrointestinal (GI) and $55(28 \%)$ GI bleeds. Overall mortality was $59 \%(n=72), 34(28 \%)$ and $38(31 \%)$ following non-GI and GI bleeds respectively. The prevalence of therapeutic invasive interventions was $7.5 \%$ and $16.3 \%$ in non-GI and $\mathrm{Gl}$ bleeds respectively and all were successful in resolving the bleeding event. We found that having a GI bleeds was associated with higher risk of mortality compared to non-GI bleeds $(p=0.04)$ and having occult bleeds to be associated with 15 times increased risk of mortality. Furthermore, patients who were on therapeutic dose of anticoagulation were more likely to die compared to patients who were on none (odds ratio (OR) $0.1,95 \% \mathrm{Cl} 0.01-0.86$ ), on prophylactic (OR $0.07,95 \% \mathrm{Cl} 0.02-0.28)$ or intermediate (OR $0.36,95 \% \mathrm{Cl} 0.09-1.34$ ) anticoagulation doses.

\section{Conclusions}

Routine prescription of supra-prophylactic dose anticoagulation should be revisited as it appears to be associated with increased of mortality and so more individualized approach to prescription should be the norm. Regardless of the cause of bleeding event it appears that the majority of bleeding events resolve with noninvasive interventions, correction and optimization sepsis therapies. However, when invasive interventions were necessary, they were associated with high success rate despite the delay.

\section{Background}

The rapid emergence of the novel coronavirus 19 (COVID-19) has brought the world to a standstill. The transmissibility and associated morbidity and mortality of this virus have overwhelmed many worldwide healthcare systems, resulting in an urgent need to understand this virus and its associated effects better.

It appears that the principal cause of death is acute respiratory failure complicated by a concomitant coagulation disorder that can induce disseminated intravascular coagulation (DIC) (1). In light of this, anticoagulation therapy has been introduced recently as an adjuvant treatment, showing promising results in term of reducing mortality rate in several small retrospective studies (2). As a result, many organizations including the international society of thrombosis and hemostasis (ISTH) are recommending specific anticoagulation regimens for COVID-19 patients (3). Recommendations included 
the use of low molecular weight heparin (LMWH) at various doses or unfractionated heparin (UFH) infusions in COVID-19 patients with elevated D-dimer levels but no known thrombotic complications (45). However, others have argued against empiric escalation of anticoagulation due to fears of a potential still unquantified increased risk of bleeding (6). Furthermore, COVID-19 induced thrombocytopenia and DIC has been hypothesis to contribute to further increased risk of bleeding as a direct or a sepsis induced effect (7).

Because of these changes in practice, we predicted an increase in inpatients' surgical and gastrointestinal consults to manage patients with bleeding and hence it was imperative to appropriately identify high risk patients for bleeding so that we can mitigate potential bleeding episodes and the associated morbidities and mortality. To date there is a lack in studies evaluating risk factors associated with increased risk of gastrointestinal (GI) and non GI bleeding events, as well as factors associated with the resolution of bleeding episodes after interventions and the risk of mortality following bleeding events in patients with COVID-19 on anticoagulation. Our study aims to be the first to investigate these.

\section{Methods}

The study was approved by Kuwait Ministry of Health Ethical Review Board.The study was approved by Kuwait Ministry of Health Ethical Review Board. All patients admitted to Jaber Al-Ahmad Al-Sabah hospital in Kuwait, with a diagnosis of COVID-19, based on the World Health Organization (WHO) interim guidance (8) and have been confirmed by laboratory testing using polymerase chain reaction (PCR) testing, between March 2020 and June 2020 were included. Patients who had equivocal PCR tests were excluded from the study.

\section{Data collection}

Data regarding patients' demographics, baseline characteristics, inpatient therapies, complications, at time of consultations symptoms, laboratory values and interventions were collected retrospectively from the hospital electronic medical record system. These data were entered by the admitting resident prospectively.

\section{Definitions}

With regard to the anticoagulation dose, this variable was divided to either none, prophylactic, intermediate or therapeutic dose. Intermediate dose was defined as a dose which was higher the than the criteria for prophylactic dose and lower than the one for therapeutic. The intermediate dose was adjusted according to the patient's comorbidities, laboratory values such as D-dimers, and the risk of bleeding as deemed by the treating physician. Patients were counted as being on systemic steroids if they received oral or intravenous steroids for over 24 hours. Systemic steroids included prednisolone, methylprednisolone, dexamethasone, and hydrocortisone. Acute respiratory distress syndrome (ARDS) variable was classified as normal, mild, moderate or severe. Severe ARDS was defined as having $\mathrm{PaO} 2 / \mathrm{FiO} 2$ ratio of 100 or less. Moderate ARDS was defined as PaO2/FiO2 ratio of $100-200$, mild ARDS 
as $\mathrm{PaO} 2 / \mathrm{FiO} 2$ ratio of $200-300$, and normal as $\mathrm{PaO} 2 / \mathrm{FiO} 2$ over 300 . World health organization bleeding scale was used to classify bleeding severity. Grade 0 was defined as no bleeding, grade 1 was defined as minor bleeding such as petechial or mucosal bleeding, vaginal spotting and nasopharyngeal bleeding lasting less than 30 minutes. Grade 2 was defined as mild blood loss (clinically significant) such as having hematemesis, melena, gross hematuria and persistent nasopharyngeal bleeding. Grade 3 was defined as gross blood loss severe enough to require blood transfusion. Grade 4 was defined as debilitating blood loss associated with hemodynamic instability and or associated with fatality. Occult bleeding was defined as failure to identify the source of bleeding after dropping over 2 grams of hemoglobin. Patient was deemed to have sepsis if they were found to have systemic inflammatory response syndrome in response to an infectious process. We have also calculated the quick sequential organ failure assessment score (qSOFA) (value 0 to 3 ) and charlson comorbidity index (CCl) (value 0 to 9) scores for all patients. All patients diagnosed with COVID-19 stayed in the hospital until they had resolution of symptoms; defined as being afebrile for more than 72 hours and having oxygen saturations equal to or above $94 \%$, Discharge occurred after two consecutive negative PCR tests for COVID-19, more than 24 hours apart. Patients' mortality was tracked up to 30 days after bleeding event consultation.

\section{Outcome measured}

Data were analyzed in accordance with three major outcomes. First was mortality within 30 days of bleeding episode. Second was resolution of the bleeding event after consultation. Third was bleeding event outcome which was defined as either developing a GI or non-GI bleeding event. Gastrointestinal bleeding included bleeding from the upper or lower GI systems. Non-GI bleeding included all bleeding events other than $\mathrm{GI}$ bleeds such as retroperitoneal bleeding, intraperitoneal bleeding, abdominal wall hematoma, genitourinary bleed, nasopharyngeal (NPA) bleed, and central nervous system bleeds. Interventions were defined as invasive, noninvasive or hemostatic. Noninvasive intervention was defined as withholding anticoagulation/antiplatelet therapies, reducing the dose of anticoagulation, transfusion of blood products, nasal packing, bladder continuous irrigation, and or instigating medications such as proton pump inhibitors. Invasive interventions included upper endoscopy (gastroscopy, laryngoscopy and bronchoscopy), lower GI endoscopy and traditional angiography. Hemostatic interventions included a surgical operation to control the bleeding, angioembolization, use of gold probe, epinephrine injection, argon positron coagulation (APC) and hemoclips to control an active GI bleed.

\section{Statistical analysis}

Qualitative variables were expressed as numbers and percentages while quantitative variables were expressed as means and standard deviations and/or medians and interquartile ranges (IQR). We performed univariate and multivariate analyses using $R$ statistical software package (9). We imputed the missing data using the random forest algorithm implemented in MissForest R package (10). We used the univariate analyses, which included the chi-square test, two-sample t-tests and Mann-Whitney $U$ test, to assess the degree of statistical significance between the risk factors and the three selected outcomes, described above. We set a p-value equal or less than 0.1 as a threshold for selecting the risk factors for the subsequent multivariate analyses. Our multivariate analyses include three independent logistic 
regression models for each of the selected outcomes. We used a backward elimination approach and selected the final models based on the largest pseudo $\mathrm{R}^{2}$ as well as the smallest Akaike information criterion. Confounding by the demographic characteristics of the patients was assessed using the $10 \%$ threshold change in the regression coefficient approach. Finally, we evaluated how well the final models fit the data using the Hosmer - Lemeshow goodness-of-fit statistic.

\section{Results}

\section{1) Overall descriptive data}

Our surgical and GI divisions were consulted to manage bleeding episodes in 122 COVID-19 patients. There were 67 non-GI bleeds (55\%) and 55 Gl bleeds (45\%). Overall mortality was $59 \%(n=72), 34(28 \%)$ and $38(31 \%)$ deaths followed non-GI and GI bleeds respectively. World health organization grade 2 and 3 were the most common bleeding grades in the series. For non-GI bleeds the distribution of WHO bleeding grades were; WHO $0(n=0)$, WHO $1(n=12)$, WHO $2(n=36)$, WHO $3(n=18)$, WHO $4(n=1)$. For GI bleeds; WHO $0(n=6)$, WHO $1(n=7)$. WHO $2(n=20)$, WHO $3(n=22)$, WHO $4(n=0)$.

Of all 67 non-GI bleeds 5 patients (7.5\%) required invasive interventions to control the bleeding with $100 \%$ success rate to resolve the bleeding event (Table 1). Thirty-four patients died within 30 days; 7 in patients who had retroperitoneal and abdominal bleeds, 2 in patients who had hematuria, 15 in patients who had NPA bleeds, 5 in patients who had brain bleeds and 5 were unclear.

At initial assessment, of all $55 \mathrm{Gl}$ bleeds, the source of bleeding was deemed to be upper $\mathrm{Gl}$ in 12 patients, lower $\mathrm{Gl}$ in 4 patients and 39 were unknown. Eighteen patients had esophagogastroduodenoscopy (EGD) (32.7\%), and 5 had colonoscopy (9.1\%). Of the $18 \mathrm{EGD}, 13$ (72.2\%) were performed at time of consultation and $5(27.3 \%)$ after failure of conservative treatment. Of the 5 colonoscopies, $4(90 \%)$ were performed at time of consultation and $1(10 \%)$ after failure of conservative treatment. The yield rate (having a positive finding) for EGD was $88.8 \%$ (only two patients had normal EGDs) and $40 \%$ for colonoscopies (three patients had normal colonoscopes and or were diagnosed with piles). Overall, the prevalence of invasive interventions for GI bleeds was 16.3\% (8 upper and one lower GI bleeds) with 100\% success rate (Table 1$)$.

\section{DOSE OF ANTICOAGULATION}

Overall, 79 patients $(67.7 \%)$ were on therapeutic anticoagulation, 15 patients $(12.3 \%)$ were on intermediate dose, 22 patients (18\%) were on prophylactic dose and 6 patients $(5 \%)$ were on none. In the non-GI bleeding group, 45 (67\%) patients were on therapeutic anticoagulation, $9(13.4 \%)$ were on intermediate dose, $11(16.4 \%)$ patients were on prophylactic dose and $2(3 \%)$ were on none. In the GI bleeding group, 34 (62\%) were on therapeutic dose, 6 (11\%) were on intermediate dose, $11(20 \%)$ were on prophylactic dose and 4 (7.2\%) were on none. 
We identified 9 cases of retroperitoneal bleeding (7.3\%). Three patients were on prophylactic anticoagulation, five were on therapeutic dose and one was on none. Only one patient was on antiplatelet (aspirin) as well as anticoagulation. Two patients (both were on prophylactic dose) required angioembolization to control the bleeding and both were resolved. The rest resolved with no intervention. Of the 7 patients who did not require interventions 3 died within 30 days of consultation from sepsis.

We identified 2 intraperitoneal bleeding. Both patients were on therapeutic dose anticoagulation and both required angioembolization to successfully control the bleeding. However, one of the two patients died later within 30 days from sepsis.

Five patients with abdominal wall hematomas were encountered. One patient was on intermediate dose and 4 on therapeutic dose. All bleeding resolved with noninvasive interventions except one which requited angioembolization to control the bleeding. Of all patients with abdominal wall bleeding, one died within 30 days after the consultation from COVID-19 multiorgan failure.

\section{b) Hematuria}

Twelve patients had hematuria. Four patients were on prophylactic dose, five on full dose and three on intermediate dose anticoagulation. All bleeding resolved without the need for invasive intervention. Two patients died within 30 days.

\section{c) Brain}

Seven patients had cerebral bleeding events. Two patients were not on anticoagulation; one patient developed subarachnoid hemorrhage which had stabilized without intervention, however, patient later died from sepsis and the other patient survived the bleeding event. Five patients were on therapeutic anticoagulation; 4 patients expired; one as a direct consequence from intracerebral bleeding (deemed inoperable) other following combined spontaneous subdural and epidural hematomas (deemed inoperable), and 2 had hemorrhagic infarcts (died from other comorbidities within 30 days).

\section{d) Nasopharyngeal bleeding}

We identified 25 patients who had NPA bleeding. Diagnoses ranged from epistaxis, oral bleeding and tracheal site bleeding. Interventions, which were all noninvasive, included holding the anticoagulation till bleeding resolved, nasal packing and administering vitamin $\mathrm{K}$. All bleeding resolved with these techniques. Fifteen patients died within 30 days from sepsis. Of all NPA consultations, four patients were on prophylactic dose, 3 on intermediate dose, and 18 on therapeutic dose anticoagulation. Of patients who died, all were on therapeutic dose anticoagulation except two, one was on intermediate dose, and the other was on none.

GI BLEEDING 
Out of 55 patients who had signs of GI bleed at initial presentation 47 patients were managed with full dose proton pump inhibitors (PPI) and active observation, of whom 6 failed this approach and required endoscopic intervention, five EGD and 1 colonoscopy.

Of the 19 patients who had endoscopic procedures 18 EGDs and 5 colonoscopies were performed. Nine patients (16.3\%) required an endoscopic hemostatic intervention to control the bleeding, all were successful. Eight patients required upper $\mathrm{GI}$ hemostatic intervention and 1 lower GI hemostatic intervention. The upper GI interventions included gold probe, epinephrine injection, APC and hemoclips applications for bleeding ulcers. Bleeding resolved for all cases. Etiology for bleeding events were duodenal \& gastric ulcers in 10 patients (55.5\%), esophagitis and Roux-en-Y anastomosis ulcer in 1 patient, and gastritis in 5 patients $(27.7 \%)$. Three patients died within 30 days of consultation. The only lower GI endoscopic intervention was for large colonic ulcer in the cecum which was treated with APC. Bleeding resolved but patient later died from sepsis. Other colonoscopies done without interventions were for; small rectal ulcer with piles for 1 patient, ischemic colitis for 1 patient, piles for 1 patient, and one colonoscopy was essentially normal.

Overall, of 55 patients with signs of GI bleed, 38 (69.1\%) expired within 30 days of consultation. Two patients had unclear source of bleeding and died while still bleeding, both were on Plavix and therapeutic anticoagulation at the time of consultation. The rest died after resolution of the bleeding episode from COVID-19 complications.

\section{2) Demographics and baseline characteristics by primary outcomes, Univariate analysis (1) - Table 2}

\section{Mortality outcome}

Male patients $(80.56 \%)$ were significantly more likely to die than female patients. The mean age for patients who died was 60 years old. They were also significantly more likely to be admitted to intensive care unit (ICU) and had shorter hospital stay compared to patients who survived. Medical comorbidities at the time of admission did not have significant implication on the risk of mortality. These included having a history of hypertension requiring medications, asthma or chronic obstructive pulmonary disease (COPD), having complicated diabetes, remote history of myocardial infarction, or being on antiplatelets (single or dual) at the time of admission. Moreover, admission baseline hemoglobin level, before the onset of bleeding episode, did not affect the risk of mortality.

Resolution of bleeding event \& having GI bleed outcomes

Gender appears to have a significant association with bleeding resolution outcome, but it did not appear to influence the risk of having a GI bleeding compared to a non-GI bleed. ICU patients were more likely to have a GI bleed than non-GI bleed.

\section{3) Inpatient therapies and complications developed during patient's admission by primary outcomes, Univariate analysis (2) - Table 2}


The use of PPI, vasopressors, and inotropes appears to be significantly associated with the risk of death. We also found GI bleeds to be significantly associated with the need to use PPI and inotropes but not vasopressors. Furthermore, the dose but not the type of anticoagulation at the time of admission was significantly associated with risk of death following the bleeding episode. The dose of anticoagulation however did not influence bleeding event resolution or the type of bleeding.

Being on systemic steroids appears to be significantly associated with increased risk of death but not the bleeding resolution or the type of bleeding. Furthermore, being on invasive ventilation was associated with increased risk of mortality and having a GI bleed rather than a non-GI bleed. Moreover, severe ARDS was associated with higher risk of mortality, but it did not affect the bleeding resolution or the type of bleeding event. With regard to mortality outcome, having a cardiac injury, liver injury, acute kidney injury, Glasgow coma scale (GCS) less than 15, systolic blood pressure less than 100 and sepsis and high qSOFA score were associated with higher risk of death. However, the CCI score and the WHO bleeding grade did not affect the risk of death. Furthermore, having cardiac injury, liver injury, being on renal replacement therapy, having a respiratory rate over 22 , systolic blood pressure less that 100 , and sepsis appears to significantly influence the type of bleeding event. Also, the qSOFA and WHO bleeding grade but not $\mathrm{CCl}$ score significantly affected the type of bleeding event. With regard to resolution of bleeding event outcome, there was a significant association with the WHO bleeding grade. None of the complications the patients developed during admission affected bleeding resolution chance.

\section{4) At consultation symptoms, laboratory values and interventions by primary outcomes; Univariate analysis (3) - Table 2}

\section{Mortality}

Having an occult source of bleeding rather than a specific symptoms and signs indicative of a source of bleeding was significantly associated with the risk of death. Furthermore, hemoglobin level, white blood cell (WBC) count, platelet, international normalized ratio (INR), D-dimer level, e-glomerular filtration rate (eGFR) level, urea, creatinine, and $\mathrm{C}$ reactive protein (CRP) were significantly associated with the risk of death. There was no relationship between the type of intervention (invasive, noninvasive or hemostatic) and the risk of death within 30 days.

\section{Resolution of bleeding event}

We did not identify a significant relationship between any coagulation profile derangements and the ability to control bleeding episode. However, CRP and Procalcitonin (PCT) were significantly associated with bleeding resolution.

Having GI bleed outcome 
Having an occult bleed appeared to be significantly associated with having a GI bleed. Also, having high urea but not deranged coagulation profile was significantly associated with having a GI bleed.

Furthermore, there was a significant relationship between the type of intervention (invasive, noninvasive or hemostatic) and the type of bleeding event.

\section{5) Relationships between major outcomes - Univariate analysis (4) - Table 3}

We found having a GI bleeding event was significantly associated with the risk of death $(P=0.04)$. The prevalence of death following bleeding event was higher following a GI bleed compared to a non-GI bleed, $52.7 \%$ vs. $48.3 \%$ respectively.

\section{6) Risk factors predictors of primary outcomes}

Mortality - Multivariate logistic regression (1) - Table 4

Patient who had longer hospital stay appeared to be less likely to die, odds ratio (OR) $0.95(95 \% \mathrm{Cl}, 0.92-$ $0.98, p=0.003$ ). We also found that patients who were on therapeutic dose of anticoagulation were more likely to die compared to patients who were on none, on prophylactic or intermediate anticoagulation doses. This risk appears to be significant when therapeutic dose was compared to prophylactic dose, OR $0.07(95 \% \mathrm{Cl} 0.02-0.028, \mathrm{p}=0.03)$ and no anticoagulation, OR $0.1(95 \% \mathrm{Cl} 0.97-0.99, \mathrm{p}<0.00)$ but not significant when compared to intermediate dose, OR $0.36(95 \% \mathrm{Cl} 1.02-1.15, \mathrm{p}=0.13)$. Furthermore, having an occult bleeding appeared to be a significant predictor of risk of death, OR 15 (95\% Cl 1.97-29.1, p= 0.013). Also, WBC and platelet levels appeared to independently affect risk of death.

Resolution of bleeding event - multivariate logistic regression (2) - Table 5

Patients who were on PPI were more likely to have resolution of bleeding event compared to patients who were not. Out of all GI symptoms and signs melena appeared to be significantly associated with lower odds of bleeding resolution, OR $0.03(95 \% \mathrm{Cl} 0.01-0.18, \mathrm{p}<0.00)$. C-reactive protein appeared as well to be significantly associated with lower odd of bleeding resolution, OR $0.98(95 \% \mathrm{Cl} 0.97-0.99, \mathrm{p}<0.00)$.

\section{Type of bleeding event - multivariate logistic regression (3)- Table 6}

The risk of $\mathrm{GI}$ bleeding increased when patient was on inotropes (OR 7.33, 95\% $\mathrm{Cl} 1.03-55.28, \mathrm{p}=0.005)$, had cardiac injury $(\mathrm{OR} 6.73,95 \% \mathrm{Cl} 0.92-49.43, \mathrm{p}=0.06)$, had liver injury $(\mathrm{OR} 74.08,95 \% \mathrm{Cl} 4.18-132.08, \mathrm{p}=$ $0.03)$, had qSOFA score of $3(\mathrm{OR} 23.43,95 \% \mathrm{Cl} 4.94-374.73, \mathrm{p}=0.02)$, had hematemesis (OR $19.79,95 \% \mathrm{Cl}$ 2.23-175.74 $p=0.00)$, and had occult bleed (OR $32.24,95 \% \mathrm{Cl} 3.34-311.08, p=0.00)$. The mortality variable had poor correlation with the type of bleeding event on multivariate analysis model and so it was removed from the model.

\section{Discussion}


To our knowledge, this is the largest and first study to evaluate the risk factors associated with $\mathrm{GI}$ and surgical bleeding events in patients with COVID-19.

In our population WHO grade, which is representative of the volume of blood lost and thus indirectly blood transfusion requirements, did not affect the risk of mortality. The majority of the bleeding events encountered in our population were WHO 2 or $3(78.6 \%)$. This moderate degree of bleeding likely did not lead to hemodynamic instability and thus did not generate enough force to tip the patient toward shock when they were not or worsened an existing shock. Furthermore, we found newly developed, in hospital, medical comorbidities rather than pre-existing ones before admission to carry more weight on increasing the risk of mortality following a bleeding event. Charlson score, contains both pre-existing and newly developed medical comorbidities, and qSOFA score contains only acute ones. We found CCI score did not to affect the risk of mortality, but qSOFA score, acute cardiac injury, acute liver injury, acute kidney injury, in hospital GCS less than 15, in hospital systolic blood pressure less than 100, and sepsis, were significantly associated with increased risk of mortality.

Due to the hypothesized hemostatic derangement observed with COVID-19 which causes a microthrombosis induced multiorgan failure and death (11) clinicians have been routinely prescribing intermediate and full therapeutic doses rather than prophylactic dose anticoagulation to prevent this presumed phenomenon. Helms et al recently reported at least $40 \%$ thrombotic complications in patients with COVID-19 (12), and Tang et. (13) al. has suggested mortality benefits with the use of anticoagulation in COVID-19 patients. However, all these studies suffer from small samples size and limited exploration of the known potential negative implications of higher doses of anticoagulation use. In our population we noticed that the majority of patients who had head and neck bleeds (brain and NPA) ended up dying. Patients with brain bleeds who died in our population were deemed inoperable and all of them were on therapeutic anticoagulation. Of all deaths in NPA bleeds all were on therapeutic and or intermediate dose anticoagulation except one. Dogra et al. (14) reported $4.4 \%$ of 755 patients diagnosed with COVID-19 were found to have $\mathrm{ICH}$ on concurrent neuroimaging, of whom the majority of these patients were on therapeutic anticoagulants. These are all indications that being on "supra-prophylactic" dose anticoagulation can put patient at increased risk of fatal head and neck bleeds. In our population, with regards to brain bleeds, it appears to be associated with high risk of mortality because by the time it happened intervention seems too late in typical patient with limited physiological reserve in context of COVID-19 sepsis. With regards to NPA bleeds, despite bleeding resolution in all events, significant proportion of patients eventually expired. This might be because the progressive "lingering" COVID-19 associated platelet dysfunction and DIC rather than the acute bleeding event itself are the major contributors to the eventual death of patient with COVID-19 and so NPA bleeds should be considered red flags for aggressive persistent COVID-19 coagulopathy, multiorgan failure and eventual death. Thus, efforts should be focused on correction and optimization of COVID-19 sepsis therapies and anticoagulation should be administered with caution in head neck bleeds subpopulation.

We are the first to identify a significant association between the dose of anticoagulation in the setting of bleeding event and risk of death. Specifically, we found patients who were on prophylactic dose or no 
anticoagulation appeared to be on lower risk of death compared to patient on therapeutic anticoagulation by $7 \%$, and $10 \%$ respectively. When therapeutic dose was compared to intermediate dose, there was no significant difference in the risk of death. These findings put into question the routine unopposed practice of prescribing "supra-prophylactic dose" anticoagulation to newly admitted COVID-19 patients and probably these doses should be prescribed in selective cases only.

Moreover, we found that the dose of anticoagulation did not influence the risk of bleeding resolution nor the type of bleeding. This might suggest that regardless of the dose of anticoagulation patient is on, noninvasive interventions such as withholding anticoagulation following bleed event, rather than an invasive or hemostatic intervention are the major determinants of bleeding resolution, and so should always be considered as first and primary line of intervention. This approach will save valuable resources and spare health care professionals unnecessary exposure.

Samkari et. al. (5) retrospective study of 400 admitted COVID-19 patients who were primarily receiving prophylactic dose of anticoagulation reported thrombocytopenia at initial presentation to be significant predictor of bleeding. In our study, we found, "chemical thrombocytopenia", being on antiplatelets therapy (single, dual or even the novel ones), did not affect the risk of mortality, resolution of bleeding events nor the type of bleeding. This might indicate that sepsis induced platelet dysfunction and eventually shock rather than thrombocytopenia itself significantly interact with bleeding events variables.

In general, in acute $\mathrm{GI}$ bleeding events, endoscopy remains the first line intervention within 24 hours of patient stabilization. However, with the era of COVID-19, the risk benefits equation got more complex by concerns for provider safety and a need to preserve personal protective equipment. Moreover, there are limited data on the diagnostic and therapeutic benefits of endoscopy in this cohort, leaving endoscopist with inadequate information and algorithms to guide their decision of when the risk of endoscopy outweigh the benefits. In our population the prevalence of instigating diagnostic or therapeutic endoscopic is relatively low. However, this does not appear to be unique to our center. Salerno et. al. (15) looked at the impact of COVID-19 on urgent endoscopy in Italy. They reported a significant reduction in the number of urgent upper and lower GI endoscopy by $80 \%$ and $55 \%$ respectively. This reduction in endoscopy use was replicated in a Belgium study which reported $40 \%$ reduction in upper GI bleeding events requiring endoscopy (16). Salerno et. al also reported that the significant reduction in endoscopy use was associated with increase in diagnostic yield by over $10 \%$ in the upper $\mathrm{Gl}$ endoscopy group. This correlate well with our findings. Where even though our use of endoscopy to investigate our GI bleeding events was relatively low, as endoscopy was preserved for patients with clinically significant GI bleed and those who failed conservative therapy, our diagnostic yield was relatively high for both upper and lower GI endoscopy, $88.8 \%$ and $60 \%$ respectively.

Martin et. al. (17) conducted a match case control study of 41 patients with COVID-19 who had bleeding events (31 upper GI and 10 lower GI bleeds) compared to 82 COVID-19 patients who did not have GI bleeds. They found no difference in presenting symptoms and signs, no difference in severity of COVID19 manifestations, and no difference in anticoagulation use. They reported most common cause of upper 
GI bleed was duodenal ulcer (80\%), ours was $55.5 \%$ duodenal \& gastric ulcers. For lower GI bleeding event they reported rectal tube insertions to be the most common cause (60\%), our hospital does not use rectal tubes routinely. In their study, hemostatic interventions where successful in all cases who required intervention $(n=7)$, with no immediate postprocedural complications happened, and no interventional radiology or surgical procedures were required. We had similar experience with $100 \%$ successful interventions for both non-GI and GI bleeds for all hemostatic interventions attempts. On multivariate analysis they found having a previous history of upper $\mathrm{GI}$ bleed to be the only predictor of upper $\mathrm{GI}$ bleeding. We found being on inotropes, having liver injury, high qSOFA score, having hematemesis, and occult bleeding to be significant predictor of having a GI bleed. Furthermore, they found trends toward higher risk of upper and lower bleeding events with being on anticoagulation, but this was not statically significant. We as well did not find a significant relationship between the dose of anticoagulation and the risk of having a GI bleed. Similar to Martin et. al. the majority of our study bleeding events ultimately had cessation of bleeding without the need for hemostatic intervention. Furthermore, our GI bleeding population had high mortality rate $(69 \%)$ despite bleeding resolution in the majority of cases. Based on all that, in COVID-19 era it appears to be safe to delay instigating endoscopic an intervention for GI bleeds, contrary to most guidelines which recommends early intervention for bleeding events. This will help alleviate concerns toward patient's respiratory status or illness severity, provider safety, PPE conservation, and the preservation of ventilators and avoiding procedural related intubations.

Finally, we found having a GI bleed was significantly associated with increased risk of mortality $(\mathrm{p}=$ 0.04), despite bleeding event resolution in the majority of cases. We also found having an occult bleed was associated with 15 times increased risk of death. This suggests that slow non profound bleeding as a consequence of COVID-19 coagulopathy might be a more significant contributor to increased risk of mortality rather an acute bleeding episode which is normally associated with hard signs of bleeding such as hematemesis and melena. Based on that, efforts probably should be focused on correction of coagulopathy and sepsis rather than none targeted invasive GI interventions in patient with COVID-19, since most of these patients do not have identifiable source of bleeding amendable to invasive hemostatic intervention.

\section{Limitations}

One major limitation of the present study was that it was derived from a single institutional crosssectional study with inherent selection and information bias, hence generalizability of the findings to larger populations might not be representative. Further, our study had a limited sample size which led to the inflation of the ORs $95 \% \mathrm{Cl}$, rendering them notably less precise. However, our inferences were based on all available data on rare outcomes that were collected within a short time during the current pandemic. Therefore, future studies should be focused on collecting more data to additionally validate our results.

\section{Conclusions}


As COVID-19 pandemic evolves, surgeons and gastroenterologists are being confronted with unique challenges, particularly understanding the bleeding sequala of this novel virus. With the increasing use of supra-prophylactic doses of anticoagulation in this subpopulation the incidence of bleeding events, both surgical and $\mathrm{Gl}$, will be on the increase. We are the first to identify a significant association between the dose of anticoagulation and risk of mortality. The previously unchallenged recommendation to prescribe therapeutic and or intermediate doses of anticoagulation to all newly admitted patients with COVID-19 should be revisited and more individualized approach to prescription should be the norm.

Gastrointestinal bleeds appear to be associated with increased risk of mortality compared to non-GI bleeds, however, regardless of the source of bleeds the majority of bleeding events in COVID-19 patients appear to resolve with noninvasive interventions and when hemostatic interventions were necessary it had high success rate, despite the delay. This means that conservative management at the time of consultation seems to be a reasonable initial approach managing these complex cases, as most cases will resolve without the need for intervention. This alleviates concerns regarding provider safety, and the need to preserve personal protective equipment without jeopardizing patient safety and outcomes.

With regards to $\mathrm{GI}$ bleeds, endoscopic intervention should be limited to patients with hard signs of $\mathrm{GI}$ bleeds, such as hematemesis or melena. In patients with occult bleed efforts might be better geared toward optimizing therapies that manage COVID-19 sepsis induced coagulopathy, DIC and shock rather than none target low yield endoscopic interventions.

\section{Abbreviations}

COVID-19: Coronavirus disease 19

Gl: gastrointestinal

DIC: disseminated intravascular coagulation

ISTH: the international society of thrombosis and hemostasis

LMWH: low molecular weight heparin

UFH: unfractionated heparin

WHO: World Health Organization

PCR: polymerase chain reaction

ARDS: Acute respiratory distress syndrome

qSOFA: quick sequential organ failure assessment score

CCl: charlson comorbidity index 
NPA: nasopharyngeal

APC: argon positron coagulation

IQR: interquartile ranges

EGD: esophagogastroduodenoscopy

PPI: proton pump inhibitors

ICU: intensive care unit

COPD: chronic obstructive pulmonary disease

GCS: Glasgow coma scale

WBC: white blood cells

INR: international normalized ratio

eGFR: e-glomerular filtration rate

CRP: C reactive protein

PCT: Procalcitonin

OR: odds ratio

\section{Declarations}

\section{Ethics approval \& consent to participate:}

The Ministry of Health of Kuwait which is the government branch at the state of Kuwait which manage Jabir AL-Ahmad Hospital (our study center) approved the study.

Since the this is a retrospective review of prospectively maintained database, patient consent was not required to get ethical approval. To ensure patient confidentiality patient identification data were anonymized.

\section{Consent for publication section:}

The ethics committee approved publication of this manuscript

\section{Availability of data and material:}


The dataset used and/or analysed during the current study available from the corresponding author on reasonable request

\section{Finding:}

No funding was obtained for this study

\section{Authors' contribution:}

All authors read and approved the manuscript

AA contributed to study concept, design, data collection, analysis, draft preparation and final submission YA contributed to study concept, design, data collection, analysis, draft preparation and final submission KA contributed to study concept, design, data collection, analysis, draft preparation and final submission EL contributed to study concept, design, data collection, analysis, draft preparation and final submission MA contributed to study concept, design, data collection, analysis, draft preparation and final submission AL contributed to study concept, design, data collection, analysis, draft preparation and final submission MA contributed to study concept, design, data collection, analysis, draft preparation and final submission MJ contributed to study concept, design, data collection, analysis, draft preparation and final submission SA contributed to study concept, design, data collection, analysis, draft preparation and final submission

\section{Acknowledgments:}

Not applicable

\section{Data availability:}

All data used to create the analysis can be provided upon request

\section{References}

1. Chen T, Wu D, Chen H, Yan W, Yang D, Chen G, Ma K, Xu D, Yu H, Wang H, Wang T, Guo W, Chen J, Ding C, Zhang X, Huang J, Han M, Li S, Luo X, Zhao J, Ning Q. Clinical characteristics of 113 deceased patients with coronavirus disease 2019: retrospective study. BMJ. 2020 Mar 
26;368:m1091. doi: 10.1136/bmj.m1091. Erratum in: BMJ. 2020 Mar 31;368:m1295. PMID: 32217556; PMCID: PMC7190011.

2. Tang N, Bai H, Chen X, Gong J, Li D, Sun Z. Anticoagulant treatment is associated with decreased mortality in severe coronavirus disease 2019 patients with coagulopathy. J Thromb Haemost. 2020 May;18(5):1094-1099. doi: 10.1111/jth.14817. Epub 2020 Apr 27. PMID: 32220112.

3. Thachil J, Tang N, Gando S, Falanga A, Cattaneo M, Levi M, Clark C, Iba T. ISTH interim guidance on recognition and management of coagulopathy in COVID-19. J Thromb Haemost. 2020 May;18(5):1023-1026. doi: 10.1111/jth.14810. Epub 2020 Apr 27. PMID: 32338827.

4. Obi AT, Barnes GD, Wakefield TW, Brown S, Eliason JL, Arndt E, Henke PK. Practical diagnosis and treatment of suspected venous thromboembolism during COVID-19 pandemic. J Vasc Surg Venous Lymphat Disord. 2020 Jul;8(4):526-534. doi: 10.1016/j.jvsv.2020.04.009. Epub 2020 Apr 17. PMID: 32305585; PMCID: PMC7162794.

5. Al-Samkari H, Karp Leaf RS, Dzik WH, Carlson JCT, Fogerty AE, Waheed A, Goodarzi K, Bendapudi PK, Bornikova L, Gupta S, Leaf DE, Kuter DJ, Rosovsky RP. COVID-19 and coagulation: bleeding and thrombotic manifestations of SARS-CoV-2 infection. Blood. 2020 Jul 23;136(4):489-500. doi: 10.1182/blood.2020006520. PMID: 32492712; PMCID: PMC7378457.

6. Cattaneo M, Bertinato EM, Birocchi S, Brizio C, Malavolta D, Manzoni M, Muscarella G, Orlandi M. Pulmonary Embolism or Pulmonary Thrombosis in COVID-19? Is the Recommendation to Use HighDose Heparin for Thromboprophylaxis Justified? Thromb Haemost. 2020 Aug;120(8):1230-1232. doi: 10.1055/s-0040-1712097. Epub 2020 Apr 29. PMID: 32349132; PMCID: PMC7516356.

7. Lucatelli P, De Rubeis G, Citone M, Lucarelli NM, Pasqualini V, Sturiale M, Giuliani S, Rosati M, Ceccherini C, Corona M, Mosconi C, Utili A, Argirò R. Heparin-Related Major Bleeding in Covid-19Positive Patient: Perspective from the Outbreak. Cardiovasc Intervent Radiol. 2020 Aug;43(8):12161217. doi: 10.1007/s00270-020-02532-3. Epub 2020 May 28. PMID: 32468143; PMCID: PMC7255445.

8. World Health Organization. Clinical management of severe acute respiratory infection when novel coronavirus (nCoV) infection is suspected. WHO; 2020.

9. R Core Team. R: A language and environment for statistical computing. R Foundation for Statistical Computing, Vienna, Austria.URL: http://www.R-project.org/. . 2013; ISBN 3-900051-07-0.

10. Stekhoven, D. J. \& Bühlmann, P. Missforest-Non-parametric missing value imputation for mixed-type data. Bioinformatics 28, 112-118, doi:10.1093/bioinformatics/btr597 (2012).

11. Bikdeli B, Madhavan MV, Jimenez D, Chuich T, Dreyfus I, Driggin E, Nigoghossian C, Ageno W, Madjid M, Guo Y, Tang LV, Hu Y, Giri J, Cushman M, Quéré I, Dimakakos EP, Gibson CM, Lippi G, Favaloro EJ, Fareed J, Caprini JA, Tafur AJ, Burton JR, Francese DP, Wang EY, Falanga A, McLintock C, Hunt BJ, Spyropoulos AC, Barnes GD, Eikelboom JW, Weinberg I, Schulman S, Carrier M, Piazza G, Beckman JA, Steg PG, Stone GW, Rosenkranz S, Goldhaber SZ, Parikh SA, Monreal M, Krumholz HM, Konstantinides SV, Weitz JI, Lip GYH; Global COVID-19 Thrombosis Collaborative Group, Endorsed by the ISTH, NATF, ESVM, and the IUA, Supported by the ESC Working Group on Pulmonary Circulation 
and Right Ventricular Function. COVID-19 and Thrombotic or Thromboembolic Disease: Implications for Prevention, Antithrombotic Therapy, and Follow-Up: JACC State-of-the-Art Review. J Am Coll Cardiol. 2020 Jun 16;75(23):2950-2973. doi: 10.1016/j.jacc.2020.04.031. Epub 2020 Apr 17. PMID: 32311448; PMCID: PMC7164881.

12. Helms J, Tacquard C, Severac F, Leonard-Lorant I, Ohana M, Delabranche X, Merdji H, Clere-Jehl R, Schenck M, Fagot Gandet F, Fafi-Kremer S, Castelain V, Schneider F, Grunebaum L, Anglés-Cano E, Sattler L, Mertes PM, Meziani F; CRICS TRIGGERSEP Group (Clinical Research in Intensive Care and Sepsis Trial Group for Global Evaluation and Research in Sepsis). High risk of thrombosis in patients with severe SARS-CoV-2 infection: a multicenter prospective cohort study. Intensive Care Med. 2020 Jun;46(6):1089-1098. doi: 10.1007/s00134-020-06062-x. Epub 2020 May 4. PMID: 32367170; PMCID: PMC7197634.

13. Tang N, Bai H, Chen X, Gong J, Li D, Sun Z. Anticoagulant treatment is associated with decreased mortality in severe coronavirus disease 2019 patients with coagulopathy. J Thromb Haemost. 2020 May;18(5):1094-1099. doi: 10.1111/jth.14817. Epub 2020 Apr 27. PMID: 32220112.

14. Dogra S, Jain R, Cao M, Bilaloglu S, Zagzag D, Hochman S, Lewis A, Melmed K, Hochman K, Horwitz L, Galetta S, Berger J. Hemorrhagic stroke and anticoagulation in COVID-19. J Stroke Cerebrovasc Dis. 2020 Aug;29(8):104984. doi: 10.1016/j.jstrokecerebrovasdis.2020.104984. Epub 2020 May 23. PMID: 32689588; PMCID: PMC7245254.

15. Salerno R, Conti CB, De Silvestri A, Campbell Davies SE, Mezzina N, Ardizzone S. The impact of covid-19 pandemic on urgent endoscopy in Italy: a nation-wide multicenter study. Scand $\mathrm{J}$ Gastroenterol. 2020 Jul;55(7):870-876. doi: 10.1080/00365521.2020.1782466. Epub 2020 Jul 2. PMID: 32615891.

16. Schmiderer A, Schwaighofer H, Niederreiter L, Profanter C, Steinle H, Ziachehabi A, Tilg H. Decline in acute upper gastrointestinal bleeding during COVID-19 pandemic after initiation of lockdown in Austria. Endoscopy. 2020 Nov;52(11):1036-1038. doi: 10.1055/a-1178-4656. Epub 2020 May 14. PMID: 32408356; PMCID: PMC7653543.

17. Martin TA, Wan DW, Hajifathalian K, Tewani S, Shah SL, Mehta A, Kaplan A, Ghosh G, Choi AJ, Krisko TI, Fortune BE, Crawford CV, Sharaiha RZ. Gastrointestinal Bleeding in Patients With Coronavirus Disease 2019: A Matched Case-Control Study. Am J Gastroenterol. 2020 Oct;115(10):1609-1616. doi: 10.14309/ajg.0000000000000805. PMID: 32796176; PMCID: PMC7446989.

\section{Tables}


Table 1

Bleeding Events For Patients Who Had an Invasive Hemostatic Intervention

\begin{tabular}{|c|c|c|c|c|c|}
\hline $\begin{array}{l}\text { Type of } \\
\text { bleeding }\end{array}$ & $\begin{array}{l}\text { Anticoagulation } \\
\text { dose at bleeds }\end{array}$ & $\begin{array}{l}\text { WHO } \\
\text { grade }\end{array}$ & Intervention & Bleeding resolution & $\begin{array}{l}\text { Mortality } \\
\text { within } \\
30 \text { days }\end{array}$ \\
\hline Retroperitoneal & $\begin{array}{l}\text { Therapeutic } \\
\text { enoxaparin }\end{array}$ & 3 & Angioembolization & Yes & No \\
\hline Retroperitoneal & $\begin{array}{l}\text { Prophylactic } \\
\text { enoxaparin }\end{array}$ & 3 & Angioembolization & Yes & No \\
\hline Intraperitoneal & $\begin{array}{l}\text { Therapeutic } \\
\text { enoxaparin }\end{array}$ & 3 & Angioembolization & Yes & Yes \\
\hline Intraperitoneal & $\begin{array}{l}\text { Therapeutic } \\
\text { enoxaparin }\end{array}$ & 3 & Angioembolization & Yes & No \\
\hline $\begin{array}{l}\text { Abdominal } \\
\text { wall }\end{array}$ & $\begin{array}{l}\text { Therapeutic } \\
\text { enoxaparin }\end{array}$ & 3 & Angioembolization & Yes & No \\
\hline Cecal ulcer & $\begin{array}{l}\text { Therapeutic } \\
\text { unfractionated } \\
\text { heparin }\end{array}$ & 3 & APC & Yes & Yes \\
\hline Duodenal ulcer & $\begin{array}{l}\text { Therapeutic } \\
\text { unfractionated } \\
\text { heparin }\end{array}$ & 3 & Gold probe & Yes & No \\
\hline Duodenal ulcer & $\begin{array}{l}\text { Therapeutic } \\
\text { unfractionated } \\
\text { heparin }\end{array}$ & 3 & $\begin{array}{l}\text { APC + epinephrine } \\
\text { injection }\end{array}$ & Yes & Yes \\
\hline Duodenal ulcer & $\begin{array}{l}\text { Intermediate } \\
\text { dose } \\
\text { enoxaparin }\end{array}$ & 3 & Gold probe & Yes & Yes \\
\hline Duodenal ulcer & $\begin{array}{l}\text { Intermediate } \\
\text { dose } \\
\text { enoxaparin }\end{array}$ & 3 & Gold probe & $\begin{array}{l}\text { No - required } \\
\text { another endoscopic } \\
\text { intervention which } \\
\text { resolved the } \\
\text { bleeding }\end{array}$ & Yes \\
\hline Duodenal ulcer & $\begin{array}{l}\text { Therapeutic } \\
\text { unfractionated } \\
\text { heparin }\end{array}$ & 3 & Hemoclips & Yes & Yes \\
\hline Pyloric ulcer & $\begin{array}{l}\text { Therapeutic } \\
\text { unfractionated } \\
\text { heparin }\end{array}$ & 3 & APC & Yes & Yes \\
\hline
\end{tabular}


Table 2

Patients Demographics Baseline Characteristics. Significant p-values are boldfaced

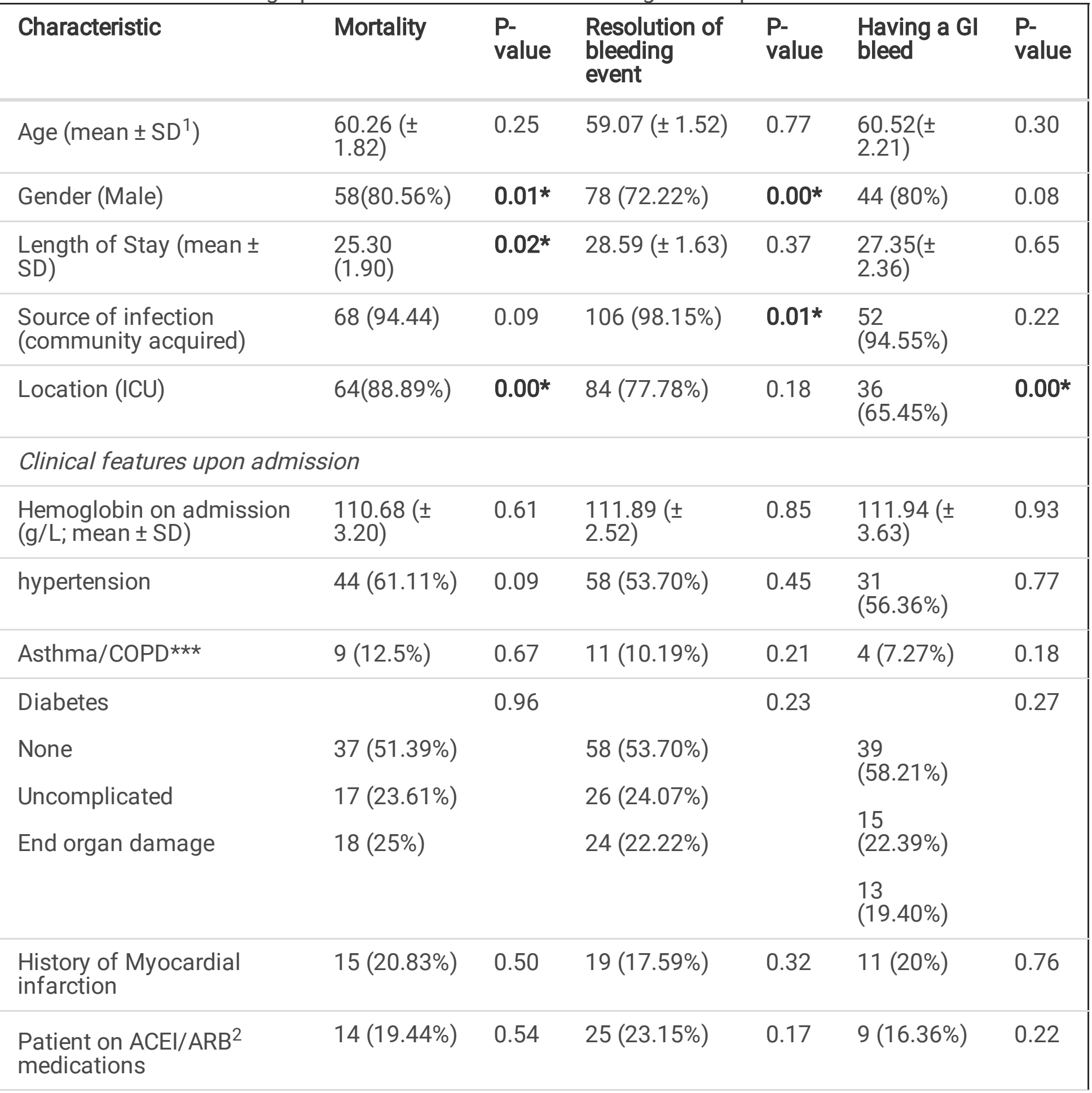

\section{SD: Standard deviation}

2. ARB/ACE: angiotensin receptors blocker/angiotensin converting enzyme inhibitor 


\begin{tabular}{|c|c|c|c|c|c|c|}
\hline Characteristic & Mortality & $\begin{array}{l}\mathrm{P}- \\
\text { value }\end{array}$ & $\begin{array}{l}\text { Resolution of } \\
\text { bleeding } \\
\text { event }\end{array}$ & $\begin{array}{l}P \text { - } \\
\text { value }\end{array}$ & $\begin{array}{l}\text { Having a GI } \\
\text { bleed }\end{array}$ & $\begin{array}{l}\mathrm{P} \text { - } \\
\text { value }\end{array}$ \\
\hline $\begin{array}{l}\text { Patient on antiplatelets } \\
\text { therapy before admission }\end{array}$ & & \multicolumn{2}{|l|}{0.36} & \multicolumn{2}{|l|}{0.53} & \multirow[t]{4}{*}{0.71} \\
\hline \multirow{3}{*}{$\begin{array}{l}\text { yes } \\
\text { no }\end{array}$} & $18(25 \%)$ & & $23(21.30 \%)$ & & \multirow{2}{*}{$\begin{array}{l}13 \\
(23.64 \%)\end{array}$} & \\
\hline & \multirow{2}{*}{$54(75 \%)$} & & \multirow{2}{*}{\multicolumn{2}{|c|}{$85(78.70 \%)$}} & & \\
\hline & & & & & $\begin{array}{l}42 \\
(76.36 \%)\end{array}$ & \\
\hline \multicolumn{7}{|c|}{ Inpatient therapies and Complications developed during patients' admissions } \\
\hline \multirow{2}{*}{$\begin{array}{l}\text { Use of proton pump } \\
\text { inhibitors }\end{array}$} & & \multicolumn{2}{|l|}{$0.04 *$} & 0.06 & & $0.00 *$ \\
\hline & $3(4.17 \%)$ & & \multicolumn{2}{|l|}{$7(6.48 \%)$} & \multicolumn{2}{|l|}{$6(10.91 \%)$} \\
\hline \multirow{2}{*}{$\begin{array}{l}\text { None } \\
\text { Prophylactic } \\
\text { Therapeutic }\end{array}$} & \multicolumn{2}{|l|}{$53(73.61 \%)$} & \multicolumn{2}{|l|}{$87(80.56 \%)$} & \multicolumn{2}{|l|}{$33(60 \%)$} \\
\hline & \multicolumn{2}{|l|}{$16(22.22 \%)$} & \multicolumn{2}{|l|}{$14(12.96 \%)$} & \multicolumn{2}{|l|}{$\begin{array}{l}16 \\
(29.09 \%)\end{array}$} \\
\hline Vasopressor & $45(62.50 \%)$ & $0.04 *$ & $57(52.78 \%)$ & 0.18 & $\begin{array}{l}27 \\
(49.09 \%)\end{array}$ & 0.24 \\
\hline Inotropes & 23 (31.94\%) & $0.00 *$ & $22(20.37 \%)$ & 0.92 & $22(40 \%)$ & $0.00 *$ \\
\hline $\begin{array}{l}\text { Patient on antiplatelet } \\
\text { therapy during admission }\end{array}$ & & \multicolumn{2}{|l|}{0.21} & 0.26 & & 0.97 \\
\hline Yes & $20(27.78 \%)$ & & \multicolumn{2}{|l|}{$\begin{array}{l}\angle 4(\angle L . \angle L \%) \\
0\end{array}$} & \multicolumn{2}{|l|}{$\begin{array}{l}13 \\
(23.64 \%)\end{array}$} \\
\hline & 52 (72.22\%) & & 84(77.78\%) & & \multicolumn{2}{|l|}{$\begin{array}{l}42 \\
(76.36 \%)\end{array}$} \\
\hline \multirow{2}{*}{$\begin{array}{l}\text { Anticoagulation dose on } \\
\text { admission }\end{array}$} & & \multicolumn{2}{|l|}{$0.00 *$} & 0.50 & & 0.65 \\
\hline & $2(2.78 \%)$ & & $6(5.56 \%)$ & & $4(7.27 \%)$ & \\
\hline & $5(6.94 \%)$ & & $21(19.44 \%)$ & & $11(20 \%)$ & \\
\hline . & $8(11.1 \%)$ & & $13(12.04 \%)$ & & $6(10.91 \%)$ & \\
\hline Full & 57 (79.17\%) & & $68(62.96 \%)$ & & $\begin{array}{l}34 \\
(61.82 \%)\end{array}$ & \\
\hline
\end{tabular}

\section{SD: Standard deviation}




\begin{tabular}{|c|c|c|c|c|c|c|}
\hline Characteristic & Mortality & $\begin{array}{l}\mathrm{P}- \\
\text { value }\end{array}$ & $\begin{array}{l}\text { Resolution of } \\
\text { bleeding } \\
\text { event }\end{array}$ & $\begin{array}{l}\mathrm{P}- \\
\text { value }\end{array}$ & $\begin{array}{l}\text { Having a GI } \\
\text { bleed }\end{array}$ & $\begin{array}{l}\text { P- } \\
\text { value }\end{array}$ \\
\hline Type of anticoagulation & & 0.09 & & 0.16 & & 0.06 \\
\hline Enoxonarin & $34(48.57 \%)$ & & $59(57.84 \%)$ & & $\begin{array}{l}28 \\
(54.90 \%)\end{array}$ & \\
\hline & $4(5.71 \%)$ & & $4(3.92 \%)$ & & \multirow{2}{*}{$4(7.84 \%)$} & \\
\hline romúpáminx & $32(45.71 \%)$ & & $39(38.24 \%)$ & & & \\
\hline Unfractionated heparin & & & & & $\begin{array}{l}19 \\
(37.25 \%)\end{array}$ & \\
\hline Inhaled steroid & $11(15.28 \%)$ & 0.39 & $16(14.81)$ & 0.12 & $11(20 \%)$ & $0.04^{*}$ \\
\hline $\begin{array}{l}\text { Systemic steroid (dose in } \\
\mathrm{mg} \text { ) }\end{array}$ & $\begin{array}{l}748.33( \pm \\
98.60)\end{array}$ & 0.10 & $\begin{array}{l}665.54( \pm \\
67.96)\end{array}$ & 0.85 & $\begin{array}{l}\text { 676.87( } \pm \\
110.99)\end{array}$ & 0.82 \\
\hline systemic steroid & & $0.00 *$ & & 0.77 & & 0.54 \\
\hline yes & $56(77.78 \%)$ & & $73(67.59 \%)$ & & $\begin{array}{l}39 \\
(70.91 \%)\end{array}$ & \\
\hline no & $16(22.22 \%)$ & & $35(32.41 \%)$ & & $\begin{array}{l}16 \\
(20.09 \%)\end{array}$ & \\
\hline Oxygen therapy & & $0.00 *$ & & 0.36 & & $0.00 *$ \\
\hline Nasal & $1(1.39 \%)$ & & $9(8.74 \%)$ & & \multicolumn{2}{|l|}{$8(14.55 \%)$} \\
\hline Mask & 0 & & $5(4.85 \%)$ & & \multicolumn{2}{|l|}{0} \\
\hline Invasive & $71(98.61 \%)$ & & $89(86.41 \%)$ & & \multicolumn{2}{|l|}{$\begin{array}{l}47 \\
(85.45 \%)\end{array}$} \\
\hline ARDS & & $0.00 *$ & & $0.00 *$ & & 0.21 \\
\hline Normal to mild & $6(8.33 \%)$ & & $24(23.30 \%)$ & & \multicolumn{2}{|l|}{$\begin{array}{l}14 \\
(25.45 \%)\end{array}$} \\
\hline Moderate to severe & $66(91.67 \%)$ & & $79(76.70 \%)$ & & \multicolumn{2}{|l|}{$\begin{array}{l}41 \\
(74.55 \%)\end{array}$} \\
\hline Cardiac injury & $22(30.56 \%)$ & $0.00 *$ & $24(22.22 \%)$ & 0.49 & $\begin{array}{l}23 \\
(41.82 \%)\end{array}$ & $0.00 *$ \\
\hline Liver injury & $11(15.28 \%)$ & $0.04^{*}$ & $11(10.19 \%)$ & 0.64 & $\begin{array}{l}12 \\
(21.82 \%)\end{array}$ & $0.00 *$ \\
\hline Acute kidney injury & $56(77.78 \%)$ & $0.01 *$ & $75(69.44 \%)$ & 0.88 & $40(72.73)$ & 0.50 \\
\hline Renal replacement therapy & $28(38.89 \%)$ & 0.08 & $35(32.41 \%)$ & 0.80 & $\begin{array}{l}25 \\
(45.45 \%)\end{array}$ & $0.00 *$ \\
\hline
\end{tabular}

\section{SD: Standard deviation}

2. ARB/ACE: angiotensin receptors blocker/angiotensin converting enzyme inhibitor 


\begin{tabular}{|c|c|c|c|c|c|c|}
\hline Characteristic & Mortality & $\begin{array}{l}\mathrm{P}- \\
\text { value }\end{array}$ & $\begin{array}{l}\text { Resolution of } \\
\text { bleeding } \\
\text { event }\end{array}$ & $\begin{array}{l}\text { P- } \\
\text { value }\end{array}$ & $\begin{array}{l}\text { Having a GI } \\
\text { bleed }\end{array}$ & $\begin{array}{l}\mathrm{P} \text { - } \\
\text { value }\end{array}$ \\
\hline GCS less than 15 & 67 (93.06\%) & $0.00 *$ & $80(74.07 \%)$ & 0.12 & $\begin{array}{l}46 \\
(83.64 \%)\end{array}$ & 0.08 \\
\hline $\begin{array}{l}\text { Respiratory rate more than } \\
22\end{array}$ & $58(80.56 \%)$ & 0.11 & $83(76.85 \%)$ & 0.30 & $\begin{array}{l}47 \\
(85.45 \%)\end{array}$ & $0.02 *$ \\
\hline $\begin{array}{l}\text { Systolic blood pressure } \\
\text { less than } 100\end{array}$ & 38 (52.78\%) & $0.00 *$ & $42(38.89 \%)$ & 0.45 & $\begin{array}{l}39 \\
(70.91 \%)\end{array}$ & $0.00 *$ \\
\hline Sepsis & 57 (79.17\%) & $0.00 *$ & $69(63.89 \%)$ & 0.97 & $\begin{array}{l}47 \\
(85.45 \%)\end{array}$ & $0.00 *$ \\
\hline qSOFA score & & $0.00 *$ & & 0.33 & & $0.00 *$ \\
\hline 0 & 0 & & $12(11.11 \%)$ & & $5(9.09 \%)$ & \\
\hline 1 & $13(18.06 \%)$ & & $22(20.37 \%)$ & & $5(9.09 \%)$ & \\
\hline 2 & 28 (38.89\%) & & $40(37.04 \%)$ & & $9(16.36 \%)$ & \\
\hline 3 & 31 (43.06\%) & & $34(31.48 \%)$ & & $\begin{array}{l}36 \\
(65.45 \%)\end{array}$ & \\
\hline $\mathrm{CCl}$ score & & 0.61 & & 0.20 & & 0.28 \\
\hline 0 & $13(26 \%)$ & & $21(19.44 \%)$ & & $\begin{array}{l}10 \\
(18.18 \%)\end{array}$ & \\
\hline 1 & $6(12 \%)$ & & $14(12.96 \%)$ & & $6(1091 \%)$ & \\
\hline 2 & $7(14 \%)$ & & $20(18.52 \%)$ & & $7(12.73 \%)$ & \\
\hline 3 & $8(16 \%)$ & & $19(17.59 \%)$ & & & \\
\hline 4 & $5(10 \%)$ & & $11(10.19 \%)$ & & $(21.82 \%)$ & \\
\hline 5 & $5(10 \%)$ & & $7(6.48 \%)$ & & $5(9.09 \%)$ & \\
\hline 6 & $2(4 \%)$ & & $7(6.48 \%)$ & & $5(9.09 \%)$ & \\
\hline 7 & $1(2 \%)$ & & $2(1.85 \%)$ & & $3(5.45 \%)$ & \\
\hline 8 & $2(4 \%)$ & & $4(3.70 \%)$ & & $1(1.82 \%)$ & \\
\hline \multirow[t]{2}{*}{9} & $1(2 \%)$ & & $3(2.78 \%)$ & & $4(7.27 \%)$ & \\
\hline & & & & & 2 (3.64\%) & \\
\hline
\end{tabular}

\section{SD: Standard deviation}




\begin{tabular}{|c|c|c|c|c|c|c|}
\hline Characteristic & Mortality & $\begin{array}{l}\mathrm{P}- \\
\text { value }\end{array}$ & $\begin{array}{l}\text { Resolution of } \\
\text { bleeding } \\
\text { event }\end{array}$ & $\begin{array}{l}\mathrm{P}- \\
\text { value }\end{array}$ & $\begin{array}{l}\text { Having a GI } \\
\text { bleed }\end{array}$ & $\begin{array}{l}\mathrm{P} \text { - } \\
\text { value }\end{array}$ \\
\hline \multicolumn{2}{|l|}{ WHO grade } & \multicolumn{2}{|l|}{0.05} & \multicolumn{2}{|l|}{$0.00 *$} & \multirow[t]{7}{*}{$0.00^{*}$} \\
\hline 0 & 0 & & $6(5.56 \%)$ & & $6(10.91 \%)$ & \\
\hline 1 & $8(16 \%)$ & & $13(12.04 \%)$ & & $3(5.45 \%)$ & \\
\hline 2 & $26(52 \%)$ & & $51(47.22 \%)$ & & \multirow{2}{*}{$\begin{array}{l}20 \\
(36.36 \%)\end{array}$} & \\
\hline 3 & \multicolumn{2}{|l|}{$16(32 \%)$} & $38(35.19 \%)$ & & & \\
\hline \multirow[t]{2}{*}{4} & \multirow[t]{2}{*}{0} & & \multirow{2}{*}{0} & & $\begin{array}{l}26 \\
(47.27 \%)\end{array}$ & \\
\hline & & & & & 0 & \\
\hline \multicolumn{7}{|c|}{ At consultation Symptoms, laboratory values, and interventions } \\
\hline Hematemesis & $10(13.89 \%)$ & 0.76 & $14(12.96 \%)$ & 0.89 & $\begin{array}{l}14 \\
(74.55 \%)\end{array}$ & $0.00 *$ \\
\hline Melena & $26(36.11 \%)$ & 0.09 & $28(25.93 \%)$ & $000 *$ & $\begin{array}{l}29 \\
(52.73 \%)\end{array}$ & 0.00 * \\
\hline Occult bleed & 11 (15.28\%) & $0.04^{*}$ & $13(12.04 \%)$ & 0.17 & $11(20 \%)$ & $0.00 *$ \\
\hline $\begin{array}{l}\text { Hemoglobin on consult } \\
\text { day }(\mathrm{g} / \mathrm{L} \text {;mean } \pm \mathrm{SD})\end{array}$ & $\begin{array}{l}77.58( \pm \\
2.26)\end{array}$ & $0.02^{*}$ & $81.81( \pm 2.14)$ & 0.39 & $\begin{array}{l}75.30( \pm \\
3.25)\end{array}$ & $0.00 *$ \\
\hline $\begin{array}{l}\text { White blood cell }\left(10^{9} / \mathrm{L}\right. \\
\text { mean } \pm \text { SD) }\end{array}$ & $\begin{array}{l}17.38( \pm \\
1.20)\end{array}$ & $0.00 *$ & $15.63( \pm 0.87)$ & 0.92 & $\begin{array}{l}16.49( \pm \\
1.39)\end{array}$ & 0.31 \\
\hline $\begin{array}{l}\text { Neutrophil }\left(10^{9} / \mathrm{L} ; \text {; mean } \pm\right. \\
\text { SD) }\end{array}$ & $\begin{array}{l}15.88( \pm \\
1.40)\end{array}$ & 0.08 & $14.25( \pm 1.19)$ & 0.81 & $\begin{array}{l}13.18( \pm \\
1.13)\end{array}$ & 0.32 \\
\hline $\begin{array}{l}\text { Lymphocytes }\left(10^{9} / \mathrm{L}\right. \\
\text {;mean } \pm \mathrm{SD})\end{array}$ & $\begin{array}{l}1.85( \pm \\
0.67)\end{array}$ & 0.87 & $1.44( \pm 1.44)$ & $0.01 *$ & $\begin{array}{l}1.18( \pm \\
0.11)\end{array}$ & 0.17 \\
\hline $\begin{array}{l}\text { Hematocrit (L/L; mean } \pm \\
\text { SD) }\end{array}$ & $\begin{array}{l}0.26( \pm \\
0.01)\end{array}$ & 0.22 & $0.87( \pm 0.59)$ & 0.70 & $\begin{array}{l}0.26( \pm \\
0.01)\end{array}$ & 0.36 \\
\hline $\begin{array}{l}\text { Platelet }\left(10^{9} / \mathrm{L} \text {; mean } \pm\right. \\
\text { SD) }\end{array}$ & $\begin{array}{l}199.41( \pm \\
14.48)\end{array}$ & $0.00 *$ & $\begin{array}{l}237.01( \pm \\
13.05)\end{array}$ & 0.20 & $\begin{array}{l}219.87( \pm \\
17.03)\end{array}$ & 0.41 \\
\hline $\begin{array}{l}\text { Prothrombin time } \\
\text { (seconds; mean } \pm \text { SD) }\end{array}$ & $\begin{array}{l}16.81( \pm \\
0.58)\end{array}$ & 0.05 & $16.03( \pm 0.39)$ & 0.16 & $\begin{array}{l}16.17( \pm \\
0.38)\end{array}$ & 0.91 \\
\hline $\begin{array}{l}\text { Activated partial } \\
\text { thromboplastin time } \\
\text { (seconds; mean } \pm S D \text { ) }\end{array}$ & $\begin{array}{l}48.15( \pm \\
2.63)\end{array}$ & 0.05 & $44.77( \pm 2.03)$ & 0.44 & $\begin{array}{l}45.98( \pm \\
3.39)\end{array}$ & 0.72 \\
\hline
\end{tabular}

\section{SD: Standard deviation}

2. ARB/ACE: angiotensin receptors blocker/angiotensin converting enzyme inhibitor 


\begin{tabular}{|c|c|c|c|c|c|c|}
\hline Characteristic & Mortality & $\begin{array}{l}P \text { - } \\
\text { value }\end{array}$ & $\begin{array}{l}\text { Resolution of } \\
\text { bleeding } \\
\text { event }\end{array}$ & $\begin{array}{l}\mathrm{P}- \\
\text { value }\end{array}$ & $\begin{array}{l}\text { Having a GI } \\
\text { bleed }\end{array}$ & $\begin{array}{l}\mathrm{P}- \\
\text { value }\end{array}$ \\
\hline $\begin{array}{l}\text { International normalized } \\
\text { ratio }\end{array}$ & $\begin{array}{l}1.23( \pm \\
0.03)\end{array}$ & $0.01 *$ & $1.17( \pm 0.01)$ & $0.00 *$ & $\begin{array}{l}1.19( \pm \\
0.02)\end{array}$ & 0.66 \\
\hline $\begin{array}{l}\text { D dimer }(\mathrm{ng} / \mathrm{mL} \text {; mean } \pm \\
\text { SD) }\end{array}$ & $\begin{array}{l}3421.37( \pm \\
234.11)\end{array}$ & $0.03^{*}$ & $\begin{array}{l}3030.11( \pm \\
203.31)\end{array}$ & 0.34 & $\begin{array}{l}3062.92( \pm \\
311.61)\end{array}$ & 0.88 \\
\hline $\begin{array}{l}\text { Fibrinogen }(\mathrm{g} / \mathrm{L} ; \text { mean } \pm \\
\text { SD) }\end{array}$ & $\begin{array}{l}5.24( \pm \\
0.18)\end{array}$ & 0.12 & $5.38( \pm 0.12)$ & 0.51 & $\begin{array}{l}5.36( \pm \\
0.17)\end{array}$ & 0.74 \\
\hline $\begin{array}{l}\text { Estimated glomerular } \\
\text { filtration rate eGFR } \\
\left(\mathrm{mL} / \mathrm{mins} / 1.73 \mathrm{~m}^{2} ; \text { mean }\right. \\
\pm \mathrm{SD})\end{array}$ & $\begin{array}{l}42.31( \pm \\
3.81)\end{array}$ & $0.00 *$ & $50.48( \pm 3.54)$ & 0.31 & $\begin{array}{l}45.36( \pm \\
4.95)\end{array}$ & 0.27 \\
\hline Urea (mmol/L) & $\begin{array}{l}26.19( \pm \\
1.74)\end{array}$ & $0.00 *$ & $22.37( \pm 1.42)$ & 0.33 & $\begin{array}{l}26.17( \pm \\
2.27)\end{array}$ & $0.02 *$ \\
\hline $\begin{array}{l}\text { Creatinine }(\mu \mathrm{mol} / \mathrm{L} \text {; mean } \\
\pm \mathrm{SD})\end{array}$ & $\begin{array}{l}255.44( \pm \\
24.98)\end{array}$ & $0.02 *$ & $\begin{array}{l}214.38( \pm \\
18.14)\end{array}$ & 0.21 & $\begin{array}{l}246.34( \pm \\
27.41)\end{array}$ & 0.21 \\
\hline $\mathrm{CRP}(\mathrm{mg} / \mathrm{L} ;$ mean $\pm \mathrm{SD})$ & $\begin{array}{l}173.69( \pm \\
12.01)\end{array}$ & $0.00 *$ & $\begin{array}{l}144.71( \pm \\
9.76)\end{array}$ & $0.01 *$ & $\begin{array}{l}145.25( \pm \\
15.22)\end{array}$ & 0.44 \\
\hline $\begin{array}{l}\text { Procalcitonin }(\mathrm{ng} / \mathrm{mL} \\
\text { mean } \pm \text { SD) }\end{array}$ & $\begin{array}{l}11.91( \pm \\
3.16)\end{array}$ & 0.11 & $7.20( \pm 1.11)$ & $0.00 *$ & $\begin{array}{l}5.44( \pm \\
0.73)\end{array}$ & 0.06 \\
\hline Noninvasive intervention & $60(83.33 \%)$ & 0.69 & $92(85.19 \%)$ & 0.52 & $\begin{array}{l}41 \\
(74.55 \%)\end{array}$ & $0.00 *$ \\
\hline Invasive intervention & $12(16.67 \%)$ & 0.92 & $17(15.74 \%)$ & 0.59 & $\begin{array}{l}14 \\
(25.45 \%)\end{array}$ & $0.01 *$ \\
\hline Hemostatic intervention & $6(8.33 \%)$ & 0.31 & $13(12.04 \%)$ & 0.17 & $8(14.55 \%)$ & 0.20 \\
\hline \multicolumn{7}{|l|}{ 1. SD: Standard deviation } \\
\hline $\sin$ & tore hlotor & tec & & & & \\
\hline
\end{tabular}


Table 3

Analyzing the Relationship Between Major Outcomes; Mortality, Resolution of Bleeding Event After Intervention and Type of Bleeding Event (having a GI bleed). Significant p-values are boldfaced

\begin{tabular}{|lllllll|}
\hline & Mortality & $\begin{array}{l}\text { P- } \\
\text { value }\end{array}$ & $\begin{array}{l}\text { Resolution of } \\
\text { bleeding event }\end{array}$ & $\begin{array}{l}\text { P- } \\
\text { value }\end{array}$ & $\begin{array}{l}\text { Having a } \\
\text { Gl bleed }\end{array}$ & $\begin{array}{l}\text { P- } \\
\text { value }\end{array}$ \\
\hline $\begin{array}{l}\text { Patient with bleeding } \\
\text { events resolved }\end{array}$ & $\begin{array}{l}61 \\
(84.72 \%)\end{array}$ & 0.11 & NA & & $\begin{array}{l}51 \\
(47.22 \%)\end{array}$ & 0.18 \\
\hline $\begin{array}{l}\text { Type of bleed } \\
\text { (Gastrointestinal) }\end{array}$ & $\begin{array}{l}38 \\
(52.78)\end{array}$ & $\mathbf{0 . 0 4 *}$ & $51(47.22 \%)$ & 0.18 & NA & \\
\hline 30 days Mortality & NA & & $61(56.48)$ & 0.11 & $38(69 \%)$ & $\mathbf{0 . 0 4 *}$ \\
\hline
\end{tabular}

Table 4

Multivariate Logistic Regression Model for Potential Risk Factors Associated with Inpatient Mortality. Significant p-values are boldfaced

\begin{tabular}{|llll|}
\hline Risk factor & Odds ratio & $\begin{array}{l}95 \% \text { confidence } \\
\text { interval }\end{array}$ & $\begin{array}{l}\text { P- } \\
\text { value }\end{array}$ \\
\hline Length of Stay & 0.95 & $0.92-0.98$ & 0.00 \\
\hline $\begin{array}{l}\text { Anticoagulation dose on } \\
\text { admission }\end{array}$ & Reference & - & - \\
Full & 0.07 & $0.02-0.28$ & 0.03 \\
Prophylactic & 0.36 & $0.09-1.34$ & 0.13 \\
Intermediate & 0.10 & $0.01-0.86$ & $<0.00$ \\
None & & & - \\
\hline Occult bleed & Reference & - & 0.01 \\
No & 15.0 & $1.97-29.1$ & 0.01 \\
Yes & 1.08 & $1.02-1.15$ & 0.00 \\
\hline White blood cell & 0.98 & $0.97-0.99$ & \\
\hline Platelet & & & \\
\hline Hosmer - Lemeshow goodness-of-fit p-value $=0.612$ & \\
\hline
\end{tabular}


Table 5

Multivariate Logistic Regression Model for Potential Risk Factors Associated With Resolved Bleeding Events. Significant p-values are boldfaced

\begin{tabular}{|llll|}
\hline Risk factor & Odds ratio & $\begin{array}{l}95 \% \text { confidence } \\
\text { interval }\end{array}$ & $\begin{array}{l}\text { P- } \\
\text { value }\end{array}$ \\
\hline $\begin{array}{l}\text { Use of proton pump } \\
\text { inhibitors }\end{array}$ & Reference & - & - \\
None & 13.04 & $3.2-136.94$ & 0.03 \\
Prophylactic & 1.24 & $0.13-14.84$ & 0.86 \\
Therapeutic & & & \\
Melena & Reference & - & - \\
No & 0.03 & $0.01-0.18$ & $<0.00$ \\
Yes & & & - \\
\hline Melena & - & - & 0.00 \\
GI bleed & 0.03 & $0.01-0.26$ & 0.00 \\
\hline No Gl bleed & 0.98 & $0.97-0.99$ & \\
\hline CRP & & & \\
\hline Hosmer - Lemeshow goodness-of-fit p-value $=0.130$ & \\
\hline
\end{tabular}


Table 6

Multivariate Logistic Regression Model for Potential Risk Factors Associated with the Type of Bleeding (having a GI bleed). Significant p-values are boldfaced

\begin{tabular}{|c|c|c|c|}
\hline Risk factor & $\begin{array}{l}\text { Odds } \\
\text { ratio }\end{array}$ & $\begin{array}{l}95 \% \\
\text { confidence } \\
\text { interval }\end{array}$ & $\begin{array}{l}\mathrm{P}- \\
\text { value }\end{array}$ \\
\hline \multicolumn{4}{|l|}{ Inotropes } \\
\hline No & Reference & - & - \\
\hline Yes & 7.33 & $1.03-55.28$ & 0.05 \\
\hline \multicolumn{4}{|c|}{ Cardiac injury } \\
\hline No & Reference & - & - \\
\hline Yes & 6.73 & $0.92-49.43$ & 0.06 \\
\hline \multicolumn{4}{|l|}{ Liver injury } \\
\hline No & Reference & - & - \\
\hline Yes & 74.08 & $4.18-132.08$ & 0.00 \\
\hline \multicolumn{4}{|l|}{ Q-sofa score } \\
\hline 0 & Reference & - & - \\
\hline 1 & 0.19 & $0.02-1.89$ & 0.15 \\
\hline 2 & 0.08 & $0.06-2.18$ & 0.06 \\
\hline 3 & 23.43 & $4.94-374.73$ & 0.02 \\
\hline \multicolumn{4}{|c|}{ Hematemesis } \\
\hline No & Reference & - & - \\
\hline Yes & 19.79 & $2.23-175.74$ & 0.00 \\
\hline \multicolumn{4}{|l|}{ Occult bleed } \\
\hline No & Reference & - & - \\
\hline Yes & 32.24 & $3.34-311.08$ & 0.00 \\
\hline
\end{tabular}

